\title{
Morphoanatomical study of the leaves of Ocotea duckei Vattimo (Lauraceae-Lauroideae)
}

\author{
Denise F. Coutinho', Maria F. Agra ${ }^{2 *}$, Ionaldo J.L.D. Basílio², José M. Barbosa-Filho \\ ${ }^{1}$ Departamento de Farmácia, Universidade Federal do Maranhão, Campus do Bacanga, \\ 65040-000, São Luís, Maranhão, Brasil, \\ ${ }^{2}$ Laboratorio de Tecnologia Farmacêutica Prof. Delby Fernandes Medeiros, Universidade Federal da Paraíba, \\ Caixa Postal 5009, 58051-970, João Pessoa, Paraíba, Brasil
}

\begin{abstract}
RESUMO: "Estudo morfoanatômico das folhas de Ocotea duckei Vattimo (LauraceaeLauroideae)". Ocotea duckei Vattimo é uma espécie nativa do nordeste brasileiro, conhecida popularmente como "Louro-de-cheiro". É rica em alcalóides, lignanas e óleos essenciais. Um dos constituintes mais importantes obtidos de Ocotea duckei é iangambina, uma lignana furorânica, que têm demonstrado várias atividades farmacológicas como: antagonista do receptor do fator de agregação plaquetária (PAF), efeito protetor contra colapso cardiovascular e choque anafilático, antialérgica, analgésica, anticonvulsivante e depressora do sistema nervosos central. $\mathrm{O}$ estudo morfo-anatômico das folhas de $O$. duckei foi realizado com o objetivo de contribuir com a sua identificação. O estudo morfológico foi realizado com auxílio de estereomicroscópio e através de observações de campo. O estudo anatômico foi feito a partir de cortes paradérmicos e transversais da folha (lâmina e pecíolo), descorados e corados com azul de astra e fucsina básica. As folha desta espécie são alternas, elípticas a oblongas, glabras, ápice agudo a acuminado e base aguda a ligeiramente atenuada. As características anatômicas principais são: epiderme uniestratificada, folha hipoestomática, com estômatos do tipo paracítico, mesofilo dorsiventral, presença de células secretoras no parênquima e feixes vasculares colaterias.
\end{abstract}

Unitermos: Ocotea duckei, Lauraceae, morfo-antomia, planta brasileira.

\begin{abstract}
Ocotea duckei Vattimo is a plant native of Northeastern Brazil and popularly know as "Louro-de-cheiro". It is rich in alkaloids, lignans and essential oils. One of the most important constituents found in Ocotea duckei is yangambin, a furofuran lignan having significant pharmacological activities: as platelet activating factor (PAF) receptor antagonist, protective against cardiovascular collapse and anaphylactic shock, anti-allergic, analgesic, anti-convulsivant and as depressant of central nervous system. A morphoanatomical study of the leaves of $O$. duckei was carried out in order to contribute to separate its from the other species of the genus Ocotea, which would be helpful in its identification. The morphological study was done with stereomicroscope and by field observations. The anatomical studies were made by paradermic and transversal sections of leaves (blade and petiole), cleared and stained with Astrablue and basic Fuchsine. The leaves are alternate, leathery, elliptic to oblong, glabrous, acute to acuminate at the apex, and acute and lightly attenuate at the base. The main anatomical features are the epidermis unistratified, the hypostomatic leaves with stomata of the paracytic type, mesophyll is dorsiventral with secretories cells in the parenchyma and collateral vascular bundles.
\end{abstract}

Keywords: Ocotea duckei, Lauraceae, morphoanatomy, Brazilian plant.

\section{INTRODUCTION}

Lauraceae is a large and predominant tropical family of trees and shrubs with 50 genera and about 3.000 species (Van der Werff, 1991). It is an important group of Angiosperm which is notoriously difficult to recognize to genus level even fertile plant (Van der Werff, 2002).

Ocotea Aublet is one of the largest genera of the Lauraceae and is comprised of about 350 species with wide distribution in the neotropical region but having a few species in Africa and Madagascar (Rohwer, 1993). In Brazil, the genus is well represented having about
150 species (Baitello, 2001). According to Van der Werff (2002), the features of Ocotea are quite variable and in not easy to separate from, being other genera of the family such as Cinnamomum and Nectandra. The difficult to make its delimitation, as a store, have been considered by Rohwer (1986) as well as the less defined genus of the family.

Ocotea duckei Vattimo, popularly known as "lourode-cheiro" and "louro-canela", is a big tree growing to about $10 \mathrm{~m}$ and it is native of the Atlantic Forest areas of Northeastern Brazil. Chemical studies of the plant showed the presence of various groups of constituents

ISSN 0102-695X 
such as, alkaloids (Silva et al., 2002; Dias et al., 2003, Morais et al. 1998a), lignans and essential oils (Morais et al., 1996; Morais et al., 1998b; Morais et al., 1999; Barbosa-Filho et al., 1999). However, its most important constituent is yangambin, a lignan isolated from the leaves that has several pharmacological properties such as selective platelet activation (PAF) receptor antagonist (Castro-Faria-Neto et al., 1995a,b; Herbert et al., 1997); anti-allergic (Serra et al., 1997); analgesic (Almeida et al., 1995), and protective against cardiovascular collapse and anaphylactic shock (Tibiriçá et al., 1996; Ribeiro et al., 1996; Araújo et al., 2001). In addition, yangambin aids in increasing the sleeping time induced by pentobarbital and the blockage of convulsion induced by pentyllenotetrazole (Pachú et al, 1993; Souza et al., 2005). Marques et al. (2003) demonstrated that this substance is not mutagenic when it was subjected to the Ames test.

Reticuline and coclaurine, the benzyltetrahydroisoquinoline alkaloids, are the other substances isolated from Ocotea duckei by Morais et al., 1998a, Silva et al., 2002 and Dias et al., 2003, respectively. Reticuline is known to produce alteration of pattern of behavior, prolongation of pentobarbital induced sleep, reduction in motor coordination, D-amphetamine-induced hyper motility and suppression of conditioned avoidance response, suggesting that it has potent depressant activity of central nervous system (Morais et al., 1998a).

Although $O$. duckei have demonstrated to be an important source of substances with pharmacological properties and there is no study done on the leaves of this plant species. The present work on the analysis of the morphoanatomical features of the leaves was carried out to aid in its identification and to distinguish it from others species of Ocotea.

\section{MATERIAL AND METHODS}

The plant material was collected in rural area of the municipality of Cruz do Espírito Santo, State of Paraíba, Brazil. Morphological studies were carried out for the botanical identification and macroscopic morphodiagnosis with fresh and fixed (formaldehyde, ethanol, acetic acid, water, 2:10:1:3,5) leaves, complemented by field observations. The voucher specimen (Agra \& Coutinho 6482) is deposited at the Herbarium Professor Lauro Pires Xavier (JPB), Universidade Federal da Paraíba.

The epidermis was obtained by scraping of both fresh and fixed material and also by dissociation using nitric $\operatorname{acid}(10 \%)$, and was stained with astrablue and basic fucsin. The transversal sections of the blade leaves and petiole were made by hand microtome, cleared by conventional methods, and were stained with safranin and astrablue. The sections were mounted in glycerin and observed at optical microscope. The terminology of Hickey (1979) was used for the architecture. The anatomical descriptions of the leaf were based on Metcalfe and Chalk (1972) and Fahn (1974). Original drawings were made with a drawing device. The photomicrographs were performed using the Axiolab Zeiss Automatic System.

\section{RESULTS}

\section{Ocotea duckei Vattimo}

Tree to 4-15 m tall; stem and branches cylindrical, green when young becoming brown in adult plant. Leaves entire, simples, alternates and glabrous; blade elliptic to oval-elliptic, leathery and shinning; the blade size has the notophyll type, $10-14 \mathrm{~cm}$ long, $3-5 \mathrm{~cm}$ wide; the shape is elliptic to oblong and symmetrical, acute to attenuate at the base, acute to acuminate at the apex, margin entire, slightly wavy, glabrous on both surfaces, discolor, being dark green and shinning in upper surface, pale green and opaque in the lower, the midrib is prominent beneath, with 7 to 8 pairs lateral veins; the petiole is marginal, glabrous, 4-7 mm long and 1-2 mm wide (Figs. $1 \mathrm{~A}$ and 4A). Inflorescence paniculate, many-flowered, 2-6 cm long. Pedicels teretes, 1-2.5 mm long, pubescent, with simple and non glandular hairs. Flowers unisexual, $5-7 \mathrm{~cm}$ long; tepals 6 , equal, pale yellow, pubescent, lanceolate to elliptic, apex acute, 3-4 mm long. Stamens 9, 2.5-3 $\mathrm{cm}$ long, filaments narrower than the anthers, which are glabrous, fertile anthers with 4 valves for liberation of pollen grains; the outer 6 stamens have one round gland (staminoid) about $1 \mathrm{~mm}$ long, at the base of each filament, which are joined to the base of the tepals; the other inner 3 stamens surround the pistil. Pistil is glabrous, $4 \mathrm{~mm}$ long, pale green; ovary globose and shorter than style; stigma-1, 3-lobed. Fruit is oblong, $0.5-3 \mathrm{~cm}$ long and 0.8$1 \mathrm{~cm}$ width with evident cupola.

Common names: "louro-de-cheiro", "louro-canela" and "louro-pimenta".

\section{Morphological characteristics of the leaf}

Architecture: Leaf with the primary vein pinnate and the secondary vein weak brochidodromous with irregular spacing and the angle is smoothly decreasing toward base. Intersecondary veins are absent. The tertiary veins are alternate percurrents and have the angle inconsistent. Quaternary veins are regular polygonal reticulate with the areolation well developed, 5 or more sided, 1-2-branched and has absent type. The marginal veinlets are classified as looped and no teethed (Fig. 4B).

\section{Anatomical characteristics of the leaf}

\section{Blade}

Epidermis: In frontal section, the epidermal cells of the blade showed wavy anticlinal walls recovered by a thick and smooth cuticle in both surfaces (Fig. 1B-C), which are smaller in the lower surface (Fig. 1C). The 

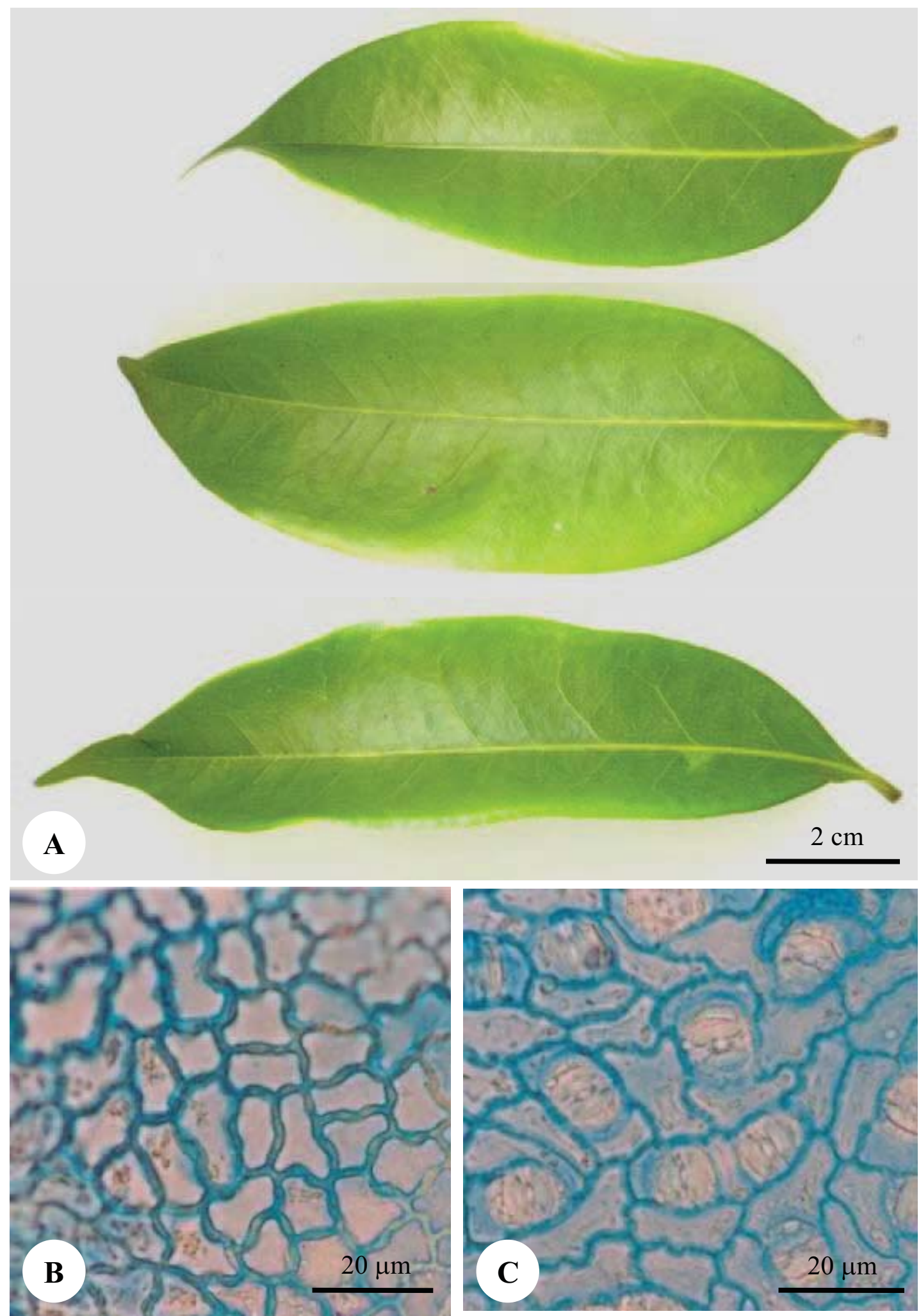

Figure 1. A. Variation of the leaf blade of Ocotea duckei Vattimo; B. Frontal view of the epidermis in adaxial surface; C. Surface view of epidermis in abaxial side showing paracitc stomata. 

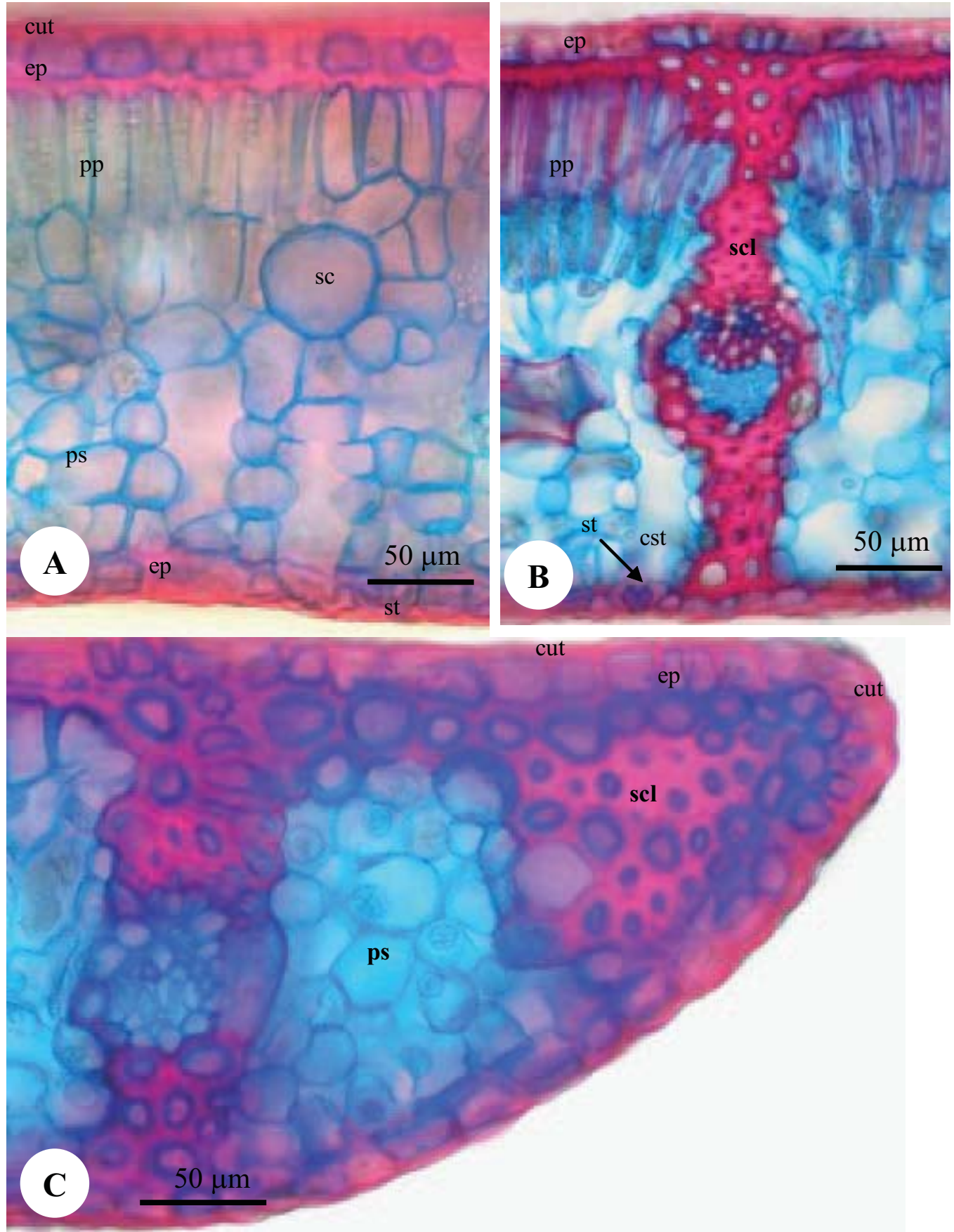

Figure 2. A. Portion of cross-section of the blade leaf of Ocotea duckei Vattimo showing the cuticular membrane on the epidermis and the mesophyll with the palisade parenchyma on the adaxial side and the spongy parenchyma on the abaxial side; B. Detail of the secondary collateral vascular bundle with sclerenchymatic sheath; $C$. Detail of the edge in medium portion of the leaf blade. Legends: secretories cells (sc), cuticle (cut), epidermal cells (ep), parenchyma palisade (pp), parenchyma spongy (ps), sclerenchyma (scl), sub-stomatal chamber (cst). 


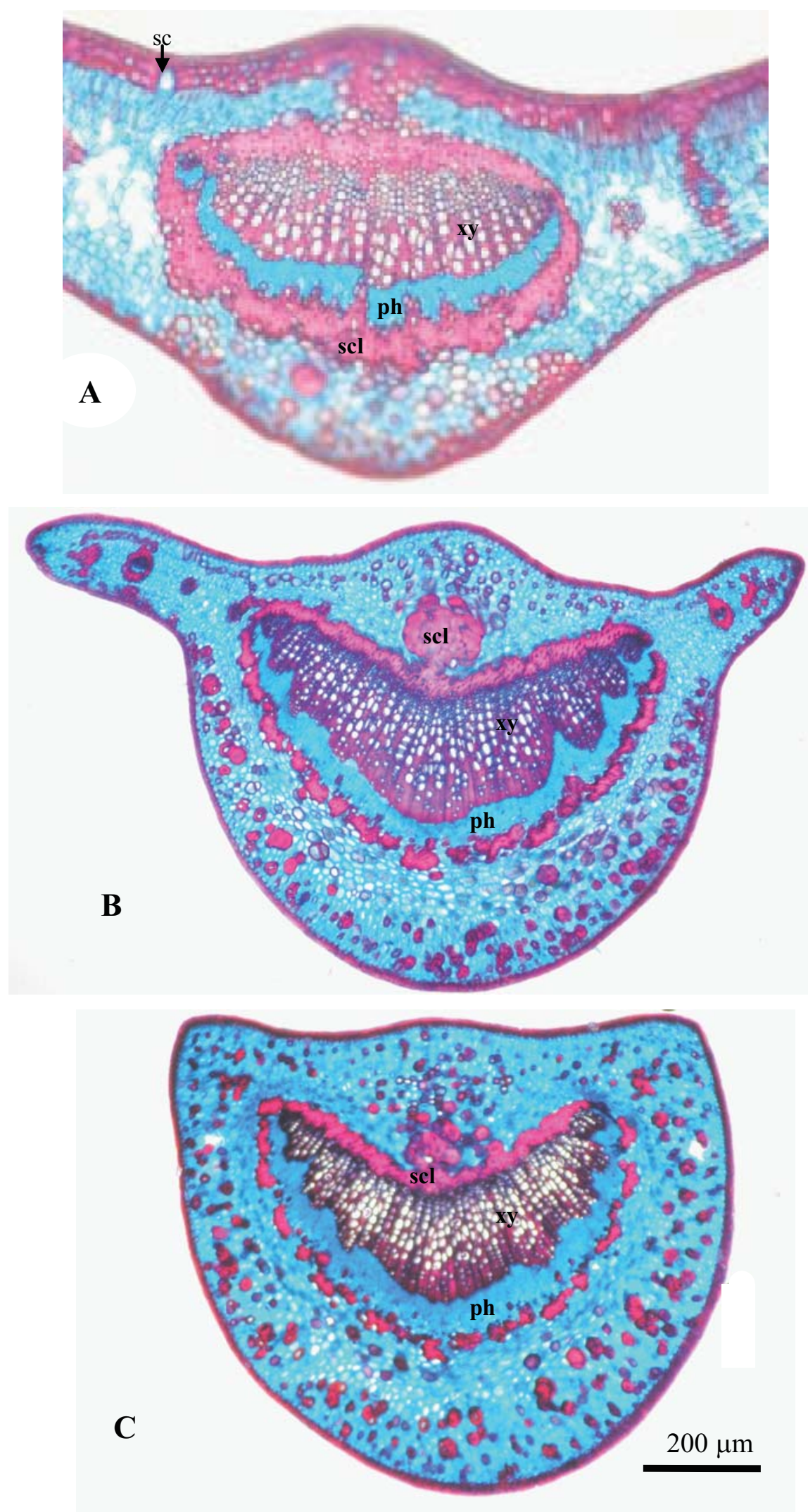

Figure 3. A. Cross-section of the blade leaf midrib in which the portion around midrib is enlarged; B-C. Cross-sections of the petiole in which can be seen the apical portion with wings lateral differing from the basal portion. Legends: xylem (xy), phloem (ph), sclerenchyma (scl), secretories cells (sc). 

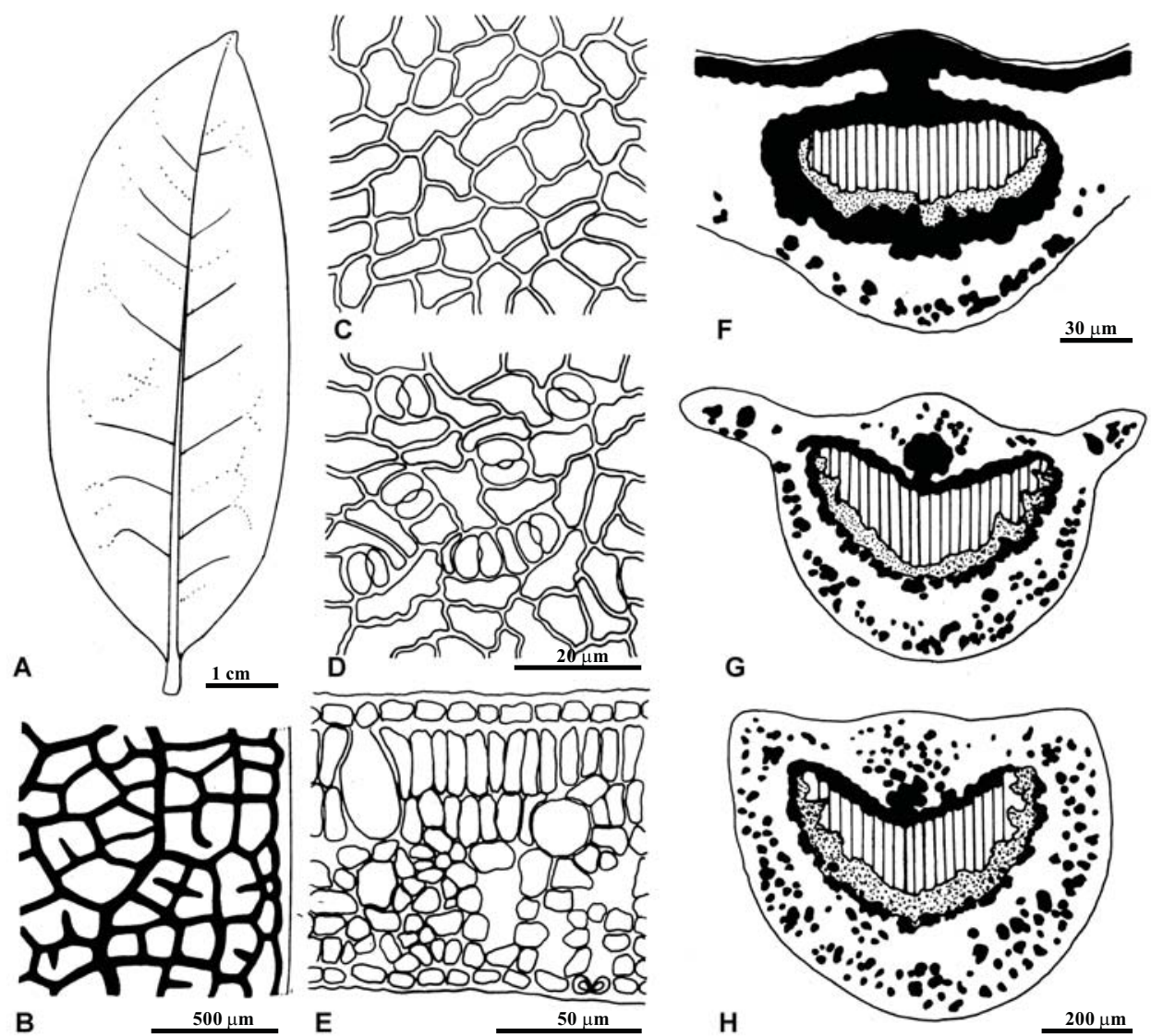

Figure 4. Diagrammatic representation of the leaf of Ocotea duckei Vattimo: A. Variations of the leaf; B. Surface view in which the marginal veins and areolation can be seen; C-D: Surface view in which the epidermis in adaxial and abaxial sides can be distinguished; E. Cross-section of the blade leaf in which can be observed the mesophyll; F. Cross-section of the midrib of the blade leaf; G-H. Cross-sections of the petiole in which the bundle is arranged in semi arch and the apical portion with lateral wings differs from the basal portion. White areas-collenchyma; stippled areas-phloem; hatched areasxylem; solid black areas-sclerenchyma.

blade leaf is hypostomatic with stomata of the paracytic type In transversal section, the epidermis is unisseriate with rectangular cells of periclinal walls that are thick and straight in the upper surface and a slowly wavy in the lower surface with sunken stomata (Fig. 2A-B).

Mesophyll: In transverse section, the mesophyll is dorsiventral with one or two layers of palisade and seven to eight layers of the spongy parenchyma (Fig. 2A-B and $4 \mathrm{E})$. In both, secretories cells ovoid to round are present with spaced distribution. The collateral vascular bundles are involved by the sclerenchymatic sheath (Fig. 2B). The edge is acute and smooth having a thick and slowly wavy cuticle and a dense sclerenchymatic sheath (Fig. 2C).

Midrib: It is biconvex and very protuberant in the lower surface (Fig. 3A and 4F). In transversal section, the midrib is composed by only one central vascular bundle semicircular to arch with a belt of continuous sclerenchymatic sheath. The annular collenchyma is followed by the cells of parenchyma, which has many sclerenchymatic fibers and round secretories cells between of these tissues. The epidermis is uniseriate with a thick cuticle. The position of xylem is turned up to the upper surface and the phloem is turned up to the lower (Fig. 3A).

\section{Petiole}

In transverse section, the petiole is plane-convex on basal and median portions, and biconvex with lateral prominences at the apical portion, winged, from the attenuated blade (Fig. 3B-C and 4G-H). The epidermis is uniseriate with rectangular and smaller cells of different 
sizes and recovered by a thick and smooth cuticle. The cortex is constituted by the fundamental parenchyma formed by many layers of sclerenchymatic cells, discontinuous surround of the vascular bundle near of the epidermis. The vascular bundle in opened V-shaped has the collateral type and is involved by sclerenchymatic sheath having only one bundle at the apex and median portions and four bundles at the base. At the apex the lateral wings are bigger than in intermediary and basal regions. The wings have a small vascular bundles in the both sides (Fig. 3B-C and 4G-H).

\section{DISCUSSION}

The leaf morphoanatomy of $O$. duckei corresponds to the foliar pattern reported for the family Lauraceae especially for the subfamily Lauroideae and for the genus Ocotea by Metcalfe and Chalk (1972). The leaf morphology and phyllotaxy of $O$. duckei follows the description by Cronquist (1981) and Judd et al. (1999) for the species of the Lauraceae family. The leaves features observed are closely similar to others species of Ocotea described by Vattimo (1961) and mislead it correct species identification among the population mainly in the young plants.

The observation of a conspicuous thick and smooth cuticle coating the adaxial epidermis is similar to those found in O. puberula by Farago et al. (2005) and contradicts partially Metcalfe and Chalk (1972), who have mentionated the punctate cuticle for the Ocotea genus. According to the latter authors, the cuticle helps to prevent the water loss efficiently, as well as the leaf from collapsing when the cells dehydrate. Moreover, the cuticle is ornamented and the occurrence of cuticular flanges have been considered of taxonomic value and used for diagnostic purposes (Metcalfe, 1979).

The occurrence of paracytic and sunken stomata confined to the lower surface in $O$. duckei are common in Lauraceae and differs from that found in O. puberula (Farago et al., 2005). The mesophyll is dorsiventral and the midrib is surrounded by a mixed sclerenchymatous sheath similar to that in the region of pericycle, which has been recorded in other species of the Lauraceae family by Metcalfe and Chalk (1972). The only citation of isobifacial mesophyll for Lauraceae was in leaves of Ocotea gardneri by Coutinho et al (2006).

The presence of secretories cells containing oil or mucilage in Ocotea duckei constitutes one of the most important characteristic feature of the Lauraceae family. According to Metcalf and Chalk (1972), it was recorded in the leaf of all investigated species belonging to different genera of the family.

\section{CONCLUSION}

Despite the lack of outstanding morphoanatomical characters for $O$. duckei the leaf showing a set of characters such as a conspicuous and sclerenchymatic ring continuous on the midrib and discontinuous in the petiole, the epidermal cells coated by a very thick cuticle, the dorsiventral mesophyll with 1-2 layers of palisade having secretories cells and ducts containing oil and mucilage that are relevant for the diagnosis of the species.

\section{ACKNOWLEDGEMENTS}

We are grateful to CNPq and CAPES for the partial financial support, and fellowships assistance to the authors. Thanks to Dr. J. Bhattacharyya for revision of the English, Dra. Maria Nilce Sousa Ribeiro, coordinator of InstitucionalQualification Program(PQI-CAPES/UFMA/ UFPB) for her personal and institutional assistance, and Dulce G. Gomes for her technical support.

\section{REFERENCES}

Almeida RN, Pachu CO, Barbosa-Filho JM 1995. Avaliação da possível atividade analgésica da iangambina obtida de Ocotea duckei Vatimo. Cienc Cult Saúde 14: 7-10.

Araújo CV, Barbosa-Filho JM, Cordeiro RS, Tibiriçá E 2001. Protective of yangambin on cardiovascular hyporeactivity to catecholamines in rats with endotoxin-induced shock. $N-S$ Arch Pharmacol 363: 267-275.

Baitello JB 2001. Novas espécies de Lauraceae para a Flora Brasileira. Acta Bot Bras 15: 445-450.

Barbosa-Filho JM, Vargas MRW, Silva IG, França LCSL, Morais EVL, Cunha MS, Silva MFV, Souza MCO, Almeida RN, Agra MF 1999. Ocotea duckei: exceptional source of yangambin and other furofuran lignans. $A n$ Acad Bras Cienc 71: 231-238.

Castro-Faria-Neto HC, Bozza PT, Cruz HN, Silva CLM, Violante FA, Barbosa-Filho JM, Thomas G, Martins MA, Tibiriçá EV, Noel F, Cordeiro RSB 1995a. Yangambin: a new naturally occuring platelet activating factor receptor antagonist: binding and in vitro functional studies. Planta Med 61: 101-105.

Castro-Faria-Neto HC, Araújo CV, Moreira S, Bozza PT, Thomas G, Barbosa-Filho, JM, Cordeiro RSB, Tibiriçá EV 1995b. Yangambin: a new naturally occuring platelet activating factor receptor antagonist: in vivo pharmacological studies. Planta Med 61: 106-112.

Coutinho DF, Agra MF, Barbosa-Filho JM, Basílio IJLD 2006. Morfo-anatomia foliar de Ocotea gardneri (Meisn.) Mez (Lauraceae-Lauroidae). Rev Bras Farmacogn 16: 178-184.

Cronquist A 1981. An Integrated System of Classification of Flowering Plants. Colombia University Press, New York.

Dias CS, Silva IG, Cunha EVL, Silva MS, Barbosa-Filho JM 2003. Isolamento e identificação de novos alcalóides de Ocotea duckei Vattimo (Lauraceae). Rev Bras Farmacogn 13(Supl): 62-63.

Fahn A 1974. Plant Anatomy. $2^{\text {th }}$ ed. Pergamon Press, Oxford. Farago PV, Budel MJ, Duarte MR, Nakashima T 2005. Análise morfoanatômica de folhas de Ocotea puberula (Rich.) Nees, Lauraceae. Rev Bras Farmacogn 15: 250-255.

Herbert JM, Castro-Faria-Neto HC, Barbosa-Filho JM, Cordeiro 
RSB, Tibiriçá E 1997. Pharmacologiacal evidence for the putative existence of two different subtypes factor PAF receptors on platelets and leukocytes studies with yangambin. J Lipid Mediators Cell Signal 17: 1-14.

Hickey LJ 1979. A revised classification of the architecture of dicotiledonous leaves. apud. Metcalfe, C.R., Chalk, L. (Eds.). Anatomy of the Dicotyledons Vol 1. $2^{\text {th }}$ ed. Oxford University Press, London, pp. 25-39.

Judd WS, Campbell CS, Kellogg EA, Stevens PF 1999. Plant Systematics: A Phylogenetic Approach. Sinauer, Sunderland, Mass.

Marques RCP, Medeiros RB, Dias CS, Barbosa-Filho JM, Agnez-Lima LF 2003. Evaluation of mutagenic potential of yangambin and of the hydroalcoholic extract of Ocotea duckei by the Ames test. Mutat ResGen Tox En 536: 117-120.

Metcalfe CR, Chalk L 1972. Anatomy of the Dicotyledons Vol 2. $4^{\text {th }}$ ed. Oxford University Press, London.

Metcalfe CR 1979. The leaf: general topography and ontogeny tissues. apud Metcalfe, C. R., Chalk, L. (Eds.). Anatomy of the Dicotyledons Vol 1. $2^{\text {th }}$ ed. Oxford University Press, London, pp. 63-75.

Morais ICSL, Pachú VI, Santos M, Barbosa-Filho JM 1996. New lignan from Ocotea duckei. Fitoterapia 67: 557.

Morais LCSL, Barbosa-Filho JM, Almeida RN 1998a. Central depressant effects of reticuline extracted from Ocotea duckei in rats and mice. J Ethnopharmacol 62: 57-61.

Morais ICSL, Pachú VI, Santos JM, Athayde-Filho PF, Almeida RN, Barbosa-Filho JM 1998b. (+)-4'$O$-demethylepimagnolin A from Ocotea duckei. Fitoterapia 69: 91-92.

Morais LCSL, Almeida RN, Cunha MS, Silva LM, BarbosaFilho JM, Gray AI 1999. Futher lignans from Ocotea duckei. Pharm Biol 71: 144-147.

Pachú CO, Almeida RN, Barbosa-Filho JM 1993. Atividade depressora do sistema nervoso central pela iangambina. Cienc Cult Saúde 12: 14-16.

Ribeiro R, Carvalho FAS, Barbosa-Filho JM, Cordeiro RSB, Tibiriçá EV 1996. Protective of yangambin-a naturaly occuring pletelet activiting factor (PAF) receptor antagonist on anaphylatic shock in rats. Phytomedicine 3: 249-256.

Rohwer JG 1986. Prodromous einer monographie der gattung Ocotea Aubl. (Lauraceae), sensu lato. Mitt Inst Allg Bot Hamburg 20: 1-278.

Rohwe JG 1993. Lauraceae. In Kubitzki K, Rohwer JG, Bittrich $\mathrm{V}$ (eds). The families and genera of vascular plants. v.2. Berlin: Springer-Velag.

Serra MF, Diaz BL, Barreto EO, Pereira APB, Lima MCR, Barbosa-Filho JM, Cordeiro RSB, Martins MA, Silva PMR 1997. Anti-allergic properties of natural PAF antagonist yangambin. Planta Med 63: 207-212.

Silva IGS, Barbosa-Filho JM, Silva MS, Lacerda CDG, Cunha EVL 2002. Coclaurine from Ocotea duckei. Biochem Syst Ecol 30: 881-883.

Sousa FCF, Lima VTM, Lacerda CDG, Barbosa-Filho JM, Viana GS 2005. Central nervous system activity of yangambin from Ocotea duckei Vattimo (Lauraceae) in mice. Phytother Res 19: 282-286.

Tibiriçá EV, Mosquera K, Abreu M, Ribeiro R, Carvalho FAS, Barbosa-Filho JM, Cordeiro RSB 1996. Antagonistic effect of yangambin on platelet activing factor (PAF)induced cardiovascular collapse. Phytomedicine 2:
235-242.

Van der Werff H 1991. A key to the genera of Lauraceae in the New World. Ann Missouri Bot Gard 78: 377-387.

Van der Werff H 2002. A synopsis of Ocotea (Lauraceae) in Central America and southern Mexico. Ann Missouri Bot Gard 89: 429-451.

Vattimo I 1961. O gênero Ocotea Aubl. no nordeste do Brasil (Lauraceae). Rodriguésia 23-24: 241-252. 